\title{
Post 9-11 Terror Hysteria: Social Work Practice and The US Patriot Act
}

\section{Fred H. Besthorn}

\begin{abstract}
It was only weeks after the planes crashed into the twin towers on that bright, sunlit morning of September 11th, 200l, that it became apparent that the most important challenge now facing American democracy was how well would we strike a balance between liberty and security. This paper will look at the history of civil liberties in light of threats to national security. It will examine components of the US Patriot Act, how these provisions are being applied and the potential implication of the act on social work education and practice. Suggestions of how social work might respond to these new realities will be discussed.
\end{abstract}

Key Words: Patriot Act, Social Work, National Security, Civil Liberty, Education

History teaches that grave threats to liberty often come in times of urgency, when constitutional rights seem too extravagant to endure. The World War II Relocation-camp cases, and the Red Scare and McCarthy-era internal subversion cases, are only the most extreme reminders that when we allow fundamental freedoms to be sacrificed in the name of real or perceived exigency, we invariably come to regret it

--Justice Thurgood Marshall's dissenting opinion in Skinner v.Railway Labor Executives Association

The accumulation of all powers, legislative, executive and judiciary, in the same hands...may justly be pronounced the very definition of tyranny.

--James Madison, Federalist Papers, 47

\section{DAYS OF TERROR YEARS OF FEAR}

It was only weeks after the planes crashed into the twin towers on that bright, sunlit morning of September 11th, 200l, that it became apparent that one of the most important challenges now to face American democracy was how well would we strike a balance between liberty and security. Adam Curtis's documentary, The Power of Nightmares: The Rise of the Politics of Fear, which I am told has been shown on British TV, but which is unavailable in America, makes the same point: liberty is often the first casualty in the rush to maintain security. Long before citizens or the government had any idea what had gone wrong in the security apparatus of the state, the assumption was, indeed, made that something had gone terribly wrong in the balance between security and liberty, and that this something was at least partially to blame for the attack's success. The assumption, haphazardly stated, just weeks after those days of terror was this: an open society had made

Fred H. Besthorn, PhD is associate professor at the Department of Social Work, University of Northern Iowa. 
America less secure and in order to be more secure we had to choose to become a less open society. Thus, one of the first non-material casualties of the war on terrorism and the rush to protect the United States from further attacks was the degree to which America, as a free society, had turned its democratic rights over to a new class of security elites who promised protection in exchange for cooperation (no dissent, restricted movement, summary imprisonment, indefinite detention and government sponsored eavesdropping). Indeed, the days of terror were giving rise to unending years of fear.

We Americans, with much hubris and feigned humility, have been fond of referring to ourselves as "the last great hope on earth" in terms of democracy, rights, and freedoms. Unfortunately, our rhetoric is far more polished than the dull glint of our burnished swagger. Indeed, in many large and subtle ways, both at home and abroad, the American government, with the silent and often compliant assent of the majority of the public has cynically abandoned its obligation to a comprehensive commitment to protect democracy, freedom, and human rights.

\section{A GOOD HISTORY GONE BAD}

The changes that have taken place in American civil liberties since 9-11 are all the starker because America played such an important role in creating the concept of international human rights in the aftermath of the carnage of World War II. The US was a pioneer in the International Human Rights movement, providing most of the language, inspiration, and moral direction for these efforts to insure civil protections and equality to all (Brown, 2003; Reichert, 2003). In reality, Eleanor Roosevelt, wife of famed US president Franklin Delano Roosevelt, was one of the principal drafters of the Universal Declaration of Human Rights - the first international document creating the framework for a vital international human rights movement. Her efforts, along with those of other prominent Americans of the post World War II period, including such luminaries of the civil Rights movement like W.E.B. Dubois, Walter White, Mordecai Johnson, and Mary McLeod Bethune, founder of the National Council of Negro Women, fully participated as activists and observers in the early conferences that gave rise to the United Nations-an international body of nations whose charter was founded upon a guarantee of fundamental human rights.

But, from the very earliest days, the high rhetoric of human rights and civil liberties has always been, for American governments and the average citizen alike, a mixed story of some very profound contradictions. On the one hand, there is a clear emphasis on the necessity of worldwide respect for human rights. On the other hand, successive American governments from Truman to Bush II have repeatedly stymied efforts to bring these rights home to our own oppressed or dispossessed minorities and, in recent years, has sought to force other nations into the so-called "freedoms of democracy" at the point of a gun. At the core of our collective moral identity as a world leader lurks the soft underbelly of hypocrisy that is clear to anyone willing to see. We began as a nation committed to a rights-based democracy, while at the same time we have attempted to collectivize this consciousness into a society largely built and maintained on the tortured and bloodied backs of slaves, Native Americans, Latinos and Pacific Islanders (Aguirre \& Turner, 2004). The commitment to grant basic human rights to some (whites, males, landholders and social elites) while denying them to others (African-Americans, Indigenous Peoples, 
women, and the poor), has been a constant moral thorn into the side of America's civic attitudes and responsibilities. We are still contending with the legacy and deep divisions of racism, sexism, and classism, manifested in a variety of different ways. We continue to embrace this historic double standard as we are one of the last remaining holdouts in the ratification of such important international initiatives as the International Convention on the Rights of the Child; the International Covenant on Economic, Social, and Cultural Rights; the movement to abolish capital punishment; and our government's visceral opposition to the International Criminal Court (Pearlstein, 2004).

\section{SUPPRESSION IN TIMES OF CRISIS}

Unfortunately, the US has a checkered history in its sometimes very open disregard for its own human rights and civil libertarian heritage (Chang, 2002; Cole \& Dempsey, 2002; Leone \& Anrig, 2003; McDougall, 2004). Several prominent examples will serve to illustrate this point.

The Sedition Act of 1798-Just over twenty years after the signing of the Declaration of Independence, and only seven years after the ratification of the Bill of Rights, the first assault on citizen's freedom of expression began. The Federalist controlled Congress passed the Sedition Act, which made it a crime to criticize the government of, then President, John Adams. The passage of this bill was justified in light of heightened tensions and talk of war between the United States and France. The intended targets of the bill all turned out to be members of the opposition party, the Republican Party, and many arrests and convictions were upheld that substantially supported a largely misguided grab for power among an elite group of hawkish internationalists within the Federalist Party. How history does seem to repeat itself.

The Habeas Corpus Act of 1863-This Act was passed to give congressional backing to President Abraham Lincoln's earlier executive order to suspend the constitutional guarantee of the writ of habeas corpus. Habeas corpus is a legal principle that requires the government to prove the legality of a person's imprisonment. In other words, it is a protection against the confinement of persons without legitimate reason and due process. But, in the early days of the American Civil War, there was a very real belief among those in power that the conflict would spell the end to American democracy and that any means necessary was justified in protecting the state. Thus, President Lincoln suspended the writ of habeas corpus and, as a result, opened the door for the detainment, without cause and for trial by military tribunal, of any citizen suspected of being disloyal to the cause of the union. Some unfortunate few were sentenced to death for their perceived, though largely unproven, complicity with the southern confederacy. Arbitrary arrests and summary imprisonment became widespread until the close of the Civil War when the US Supreme Court imposed limits on government's wartime powers.

The Espionage and Sedition Acts of 1917 and 1918-The worldwide social and political unrest of the early $20^{\text {th }}$ century and the ensuing world war led to the passage of these landmark bills. The Espionage and Sedition Acts empowered the American government to suppress and punish disloyalty and subversion, which they broadly defined to include any publication or oral utterance that would impugn the motives of government and thus lead to political dissent among the citizenry. Any publication or any person deemed to be radically disposed, socialistically inspired, or in any way contemptuous of 
the US government was subject to arrest and prosecution. The most notable examples were the arrest and imprisonment of Socialist Party members Charles Schenck and Eugene V. Debs for questioning American involvement in World War I. In a similar manner, the so-called Palmer Raids of early 1919, occurring during the height of America's first great Red Scare, were also a response to hyper-exaggerated fears of Communism and foreign born citizens. This represented the logical outcome of citizens scared into believing the worst about those different from themselves and the willingness of the average person to forfeit fundamental freedoms in the name of national security. These raids, precipitated by the bombing of Attorney General A. Mitchell Palmer's home by a foreign provocateur, led to the torture, forced detention, and summary arrest of nearly 10,000 resident aliens and the ultimate deportation of hundreds more. These government actions took place across the continental US and were supported by government sponsored vigilante groups, such as the American Protective League and National Security league. Again, a not so strange parallel to current history that sees vigilante groups like the Minutemen guarding America's southern borders with Mexico. Brinkley (2003) notes that groups like these defined their mission as:

...spying on their neighbors, eavesdropping on suspicious conversations in bars and restaurants, intercepting and opening the mail and telegrams of people suspected of disloyalty, and reporting to the authorities any evidence of disenchantment with the war effort. (p. 28)

It was not unusual for these vigilante groups to spawn and otherwise support violent action against average persons and the legitimate activities of groups deemed to be un-American or un-patriotic. German, Jewish, Irish Americans, Bolsheviks, labor-unionists, pacifists, and political dissenters were favorite targets. Reports of tar and feathering, public castration, and lynching were not uncommon.

The Smith Act of 1940 - The period up to and including World War II was another chaotic time in American history when civil liberties came under challenge with the passage of the Smith Act. This legislation made it a crime to knowingly advocate for or abet the overthrow of any duly elected governmental institution or to organize any assembly of people to encourage the overthrow of any governmental unit within the US. The Smith Act was the catalyst for one of the saddest moments in recent American history: the forced evacuation, relocation, and internment of 110,000 men, women, and children of Japanese ancestry. While no evidence was ever given for the necessity of the forced exile of this large group, two-thirds of which were American citizens, they were kept in harsh and often punitive conditions for much of the war. It was not until forty-four years later with the passage of the Civil Liberties Act of 1988 that a public apology and modest financial reparation was granted to either the detainees or their descendants.

While the Smith Act was passed during the imbroglio of World War II, its reach extended far beyond that period. The immediate post World War II period, much like the time immediately after the First World War, ushered in the second great Red Scare of the $20^{\text {th }}$ century and was the flash point for what became known as the McCarthy Era. Junior United States Senator Joseph McCarthy of Wisconsin capitalized on the fear and insecurity at the height of Cold War hysteria by chairing the infamous House Un-American Activities Committee (HUAC). Its sole purpose was to expose and root out the incipient influence of communism in American society. During this sordid chapter in American history, 
Communist Party leaders, political dissenters, liberal academics, left-leaning entertainment personalities, radical labor-unionists, and leaders of a broad range of progressive political organizations were prosecuted and convicted based solely on their political views and/or their perceived association with a worldwide communist conspiracy. Witnesses before McCarthy's committee who refused to testify against other citizens or to provide names of their associates suspected of some connection to un-American groups were imprisoned for contempt of Congress. Guilt by association became the primary mechanism that insured anyone targeted by the committee would pay a high price-whether or not evidence was ever marshaled to support the claim of un-American activities. It was common to point to any political party association or activist group that questioned or criticized the prevailing political climate as a communist front or communist-action organization and thus becoming prima-facially suspect. "In November 1950, for example, the attorney general had nearly 200 groups on a list of Communist and other subversive organizations” (Cole, 2003, p.15). Affiliation with any of these groups in any manner could lead to being called before the HUAC, and ongoing surveillance, blacklisting from employment, destruction of reputation, loss of job, or being subjected to vigilante violence. The execution of communist sympathizers and convicted spies Julian and Ethel Rosenberg was but one of the most sordid results of this disastrous time in recent US history.

COINTELPRO: 1956-1971-Government efforts to suppress political dissent and restrict civil liberties under the guise of national security did not stop with the ending of World War II or the ebbing of the Cold War. Indeed, the Federal Bureau of Investigation (FBI) operated a highly secretive counterintelligence program (COINTELPRO) that covertly spied on, interfered with, and harassed law-abiding political organizations deemed to be a threat to the stability of the US government. Its stated mission, according to an internal memo from controversial FBI director J. Edgar Hoover, was to expose, disrupt, misdirect, discredit, or otherwise neutralize activities of individuals and organizations perceived to pose a threat to domestic tranquility (Chang, 2002, p. 30). This mission was carried out through a range of activities involving a roguish repertoire of dirty tricks, including frequent use of informants and agent infiltrators to disrupt political organizations; illegal wiretaps and break-ins; and spreading false rumors and character assassinations designed to ruin personal lives, split marriages, and leading to job loss and/or public shaming. While its original purpose was to ferret out and dislodge communist sympathizes in American society, during its fifteen years of covert operations, COINTELPRO also targeted labor unions, the civil rights movement, the black nationalist movement, the women's liberation movement, the environmental movement, the new Left, and, of course, a plethora of anti-Vietnam war groups. Many prominent Americans and average citizens alike became the target of relentless FBI smear campaigns, including such people as the Reverend Dr. Martin Luther King, Jr. of the civil rights movement, Stokely Carmichael of the Black Nationalist movement, David Brower of the Sierra Club, Paul Ehrlich - a noted academic, and other prominent spokespersons in the feminist movement. The clandestine activities of the FBI and related counterintelligence groups was later and resoundingly repudiated in a scathing report from the Senate Select Committee to Study Governmental Operations with Respect to Intelligence Activities, chaired by the late Senator Frank Church. Nonetheless, many serious social critics and legal scholars agree that the full extent to which COINTELPRO significantly altered the trajectory of American political life and weakened constitutional protection will never be fully known (Brinkley, 
2003; Brown, 2003; Chang, 2002). But, unfortunately, it has not been the last attempt to circumvent the Constitution and threaten civil liberties in the name of security and patriotism. A new and potentially even more virulent effort has recently begun, mostly notably authorized in the language and provisions of the US Patriot Act.

\section{THE PATRIOT ACT}

As our previous discussion has no doubt demonstrated, the Patriot Act is not a new or particularly novel approach to an external threat to American security. On October 26, 2001, President George W. Bush, signed into law the so-called USA Patriot Act (Uniting and Strengthening America by Providing Appropriate Tools Required to Intercept and Obstruct Terrorism Act of 2001), and fourteen months later its sister legislation the Homeland Security Act. The cumulative impact of these laws and similar administrative rules, executive orders, and judicial rulings is a radical and unprecedented departure from constitutional protections. In a matter of weeks, and with little Congressional debate and even less public input, the Patriot Act sacrificed cherished civil freedoms in the name of national security and consolidates unheralded new police and intelligence powers into the hands of the president and the executive branch of government (Cole \& Dempsey, 2002; Foner, 2001; Greider, 2004; Hentoff, 2003). The Act consists of ten titles, revises fifteen existing federal statutes, and deals with various activities related to both domestic and international terrorism.

In general terms, the Patriot Act has three primary impacts on civil protections in America. One, the Act places the guaranteed 1st Amendment right of free speech and free association in jeopardy by creating a broad new crime of domestic terrorism that, in effect, gives the federal government the power to designate any person or political group a domestic terrorist if they are deemed a threat to the public order, are suspected of encouraging terrorist activities, or even if they are suspected of holding controversial views that run contrary to the current administration's foreign and domestic policy (Chang, 2002). Environmental, anti-globalization, political, and welfare activists, in addition to Arab and Muslim philanthropic organizations are prime targets. Recently, free-speaking academics, such as the case of University of Colorado professor Ward Churchill, have also come under greater scrutiny and criticism, especially in those states that have passed or are considering passage of a so-called Academic Freedom Bill of Rights, a euphemistic name for a radical neo-conservative initiative to muzzle outspoken academics (American Association of University Professors, 2005; Vanlandingham, 2005).

Secondly, the Act reduces the increasingly low expectation of personal privacy by granting all branches of law enforcement increased powers of surveillance. These powers, which are unprecedented and often unchecked, include the ability to monitor all e-mail correspondences and internet usage; conduct so-called sneak and peak searches without probable cause or court orders; and force the disclosure of sensitive personal records from third parties, including private client information from doctors, social workers, educational institutions, libraries, hospitals, social service agencies, insurance companies or any business. It also authorizes the government to monitor all financial transactions and to conduct nationwide roving wiretaps without warrant as long as the snooping has a significant likelihood of gathering intelligence on terrorist activities. The $4^{\text {th }}$ Amendment has historically granted government the right to conduct searches and wiretaps only with a 
legally proscribed probable cause to believe an individual is or has engaged in criminal activity. But the Patriot Act allows government to evade that requirement altogether if it says based upon its good word only that the search has a chance of yielding significant foreign intelligence. These unheralded data mining techniques are already being organized into a national tracking system of domestic surveillance of every person in the United States. This system is being formulated under the Department of Transportation's Computer Assisted Passenger Pre-Screening System (CAPPS II) and is what the Bush administration has referred to as Total Information Awareness. Of these kinds of programs New Times columnist William Safire (2002) wrote:

Every purchase you make with a credit card, every magazine subscription you buy and medical prescription you fill, every Web site you visit and e-mail you send or receive, every academic grade you receive, every bank deposit you make, every trip you book and every event you attend-all these transactions and communications will go into what the Defense Department describes as a "virtual, centralized grand database.”

To this computerized dossier on your private life from commercial sources, add every piece of information that government has about you-passport application, driver's license and bridge toll records, judicial and divorce records, complaints from nosy neighbors to the FBI, your lifetime paper trail plus the latest hidden camera surveillance-and you have the supersnoop's dream: a "Total Information Awareness” about every U.S. Citizen. (pg. 35)

Finally, the Patriot Act erodes the due process rights of non-citizens by allowing federal authorities to arrest foreign nationals, place them in mandatory protective detention, and even deport them based on the suspicion that their political activities may be construed as being terrorist in nature. As of late 2004, over 5,000 citizen aliens have been detained by the Department of Justice's so-called anti-terrorist sweeps (Cole, 2004). To date there have been exactly zero (0) convictions of any of these suspects for terrorist activities.

In addition to these seminal provisions of the Patriot Act, which significantly impact US civil liberties, there is other less noticeable but equally invasive aspects of the Act that deserve monitoring. The first relates to the issue of the guilt by association provision of the Act that target immigrants for deportation and exclusion. This idea is a current iteration of the anti-communist witch hunts of the McCarthy era and earlier periods of US history and make citizen aliens suspect if they are associated in any way to a terrorist organization no matter how innocent or diffuse this association. Terrorism is defined very generally by the Act. Its overly broad definition includes: (1) any act dangerous to human life that violates criminal law, (2) any acts appearing to be intended to influence policies of the government by intimidation or coercion, and (3) any acts occurring primarily in the territorial jurisdiction of the US (Romero, 2003, p. 122). Thus, the Act's very loose definition of terrorism and its proscription against associational activity makes anyone's involvement with an organization that has ever been involved in civil disobedience or has ever been party to any crime of violence or attempted to influence a governmental policy suspect-whether it be a pro-life group, or the African National Congress, or the American Civil Liberties Union, or the Irish Republican Army—since all 
have been involved at one time or another in acts of civil disobedience or some act of violence.

...the new law contains no requirement that the alien's support have any connection whatsoever to a designated organization's violent activity. Thus, an alien who sent coloring books to a day-care center run by a designated organization would apparently be deportable as a terrorist, even if she could show that the coloring books were used only by 3-year olds. Indeed, the law apparently extends even to those who seek to support a group in the interest of countering terrorism. (Cole \& Dempsey, 2002, p. 153)

In another related provision, the Patriot Act authorizes the government to deny entry into the country of any foreign-born person based solely on acts of pure speech (Chang, 2002). That is, aliens can be denied entry to the US for their political views if in the mind of the US Secretary of State this speech undermines efforts to combat terrorism. Thus, ideological exclusion is once again resurrected from the Cold War Era's McCarthyism in a manner that intends to protect Americans from hearing and thoughtfully considering ideas that may be viewed with disfavor by the government or that may run contrary to prevailing public opinion. Finally, the Patriot Act dramatically reduces judicial oversight of intrusive information gathering powers and expands the role of both the FBI and CIA-empowering them to blur the boundaries between law-enforcement and espionage activities. In the final analysis, the Bush administration has chosen to ignore the lessons of history that democracy cannot survive in the absence of free and open debate. The administration has, instead, warned Americans to watch what they say and to be careful who they associate with, thus threatening the very vitality of democracy they intend to protect.

\section{THE PATRIOT ACT AND BEYOND: SILENCING DISSENT}

In the emerging debate between fighting terrorism and protecting liberty, many well-meaning Americans strongly argue that civil liberties must be sacrificed in order to ensure public safety and maintain democratic institutions and practices. Terrorism, in and of itself, as the logic goes, seems to require that we permanently suspend constitutional protections. The radical, neo-conservative right relies on the unquestioning logic that antiterrorism measures infringing upon civil liberties will, in fact, work. But, no one can ever be sure of these premises. In reality, the opposite is likely to be true. While it is perhaps too early to assess the long term implications of a new national security state now descending on American society, a brief glance will suggest at least one very important immediate impact. Later generations may well conclude the most compelling legacy of the early $21^{\text {st }}$ century's war on terror was the silencing of political dissent. If the hard fought battles of the civil rights movement; the massive public outcry against the war in Vietnam; and the multitude of dissenting acts of the early abolitionists, suffragists, and labor organizers has taught us anything, it is that freedom of expression and the right to criticize the government is fundamental to the survival of democracy. When these hard won rights are trampled under the banner of patriotism and national unity, then we are indeed close to realizing one of the gravest warnings of our early founders. These men knew well that freedom is lost not in a single, militant assault upon the rights of persons, but in a thousand small restrictive and subversive acts, which few notice and which most believe matter 
little. In the words of Senator Russ Feingold, the only member of the US Congress to vote against the Patriot Act:

There is no doubt that if we lived in a police state, it would be easier to catch terrorists... But that wouldn't be a country in which we would want to live, and it wouldn't be a county for which we could, in good conscience ask our young people to fight and die...I think it is important to remember that the Constitution was written in 1789 by men who had recently won the Revolutionary War...They wrote the Constitution and the Bill of Rights to protect individual liberties in times of war as well as in times of peace...Preserving our freedom is the reason we are now engaged in this new war on terrorism. We will lose that war without a shot being fired if we sacrifice the liberties of the American people in the belief that by doing so we will stop the terrorists (Hentoff, 2003, pp. 24-25)

\section{SOCIAL WORK AND THE NATIONAL SECURITY STATE}

Any effective social work response to the new national security apparatus now emerging in American society must begin with the profession fully comprehending the fact that we cannot afford to sit idly by as civil liberties erode, and we cannot be silent even in the face of virulent opposition and threats to our personal safety and professional livelihood. We urgently need a coordinated and coherent view of social work education and practice in this emerging crisis and we need to find our collective voice in response. We cannot separate our professional ethics and responsibilities from the political climate around us. All things are political, as a familiar phrase goes, and we must be willing to assess and respond to the inherent friction between protecting safety and insuring freedom in this complex new world of global economism and heightened national security interests.

There are a number of issues that are beginning to confront US social workers in this new environment. First, one increasingly hears reports leaking out of service agencies that suggest increasing efforts on the part of government agents pressuring social work personnel into informing on certain of their clients. This is especially true for young, impressionable and frightened social workers engaged with refugee and immigrant communities of either Islamic or middle-eastern origin. Recent reports from my home community by social workers involved with these clients substantiates this practice (K. Ragan-Pepper, personal communication, May 3, 2005). This intentional targeting of social service workers (especially those who are new to the profession) involved with specific immigrant groups is a breech of our professional code of ethics which has historically honored the worth and dignity of each person, client self-determination, personal privacy and protection of the confidentiality of client records. It amounts to the most repulsive kind of racial, ethnic, and religious profiling and puts social workers in the very untenable position of breaching confidentiality or risk intimidation and black-listing efforts to coerce their so-called voluntary cooperation.

While reports like these are relatively few, it is likely this trend will continue because social workers are the ones who serve the most diverse groups in American society. And, of course, social work has had a checkered history of co-optation as agents of social control for the ruling establishment. The pressure will only increase for social workers to do their patriotic duty. This informal but corrosive pressure to conform is related to a second issue confronting social workers in America's current social service 
delivery system: the stigma associated with negative labeling. The tag of unpatriotic or aiding the enemy can have powerful impacts on social workers just trying to do a good job, pay their bills, and be good citizens. The statement of former attorney General John Ashcroft before the Senate Judiciary Committee just months after 9-11 is still having a chilling effect on most professions' willingness to challenge or circumvent the current administration's draconian measures to protect liberty. Ashcroft admonished that "those who scare peace-loving people with phantoms of lost liberty...your tactics only aid terrorists, for they erode our national unity and diminish our resolve", and "they give ammunition to America's enemies and pause of America's friends” (Senate Judiciary Committee, 2001, p. 10)

In the social welfare services debate the new national security state also portends a third difficulty for social work educators, student practitioners, policy advocates and other public interest groups (Piven, 2004). Advocacy requires understanding and skill in the politics of change. But, a fear of personal attack or being labeled un-patriotic or unAmerican tends to create an environment where political deliberation collapses or is subsumed under the umbrella of national unity. Crucial social and domestic policy discussions, normally hammered out in the hot fires of contentious debate and opposing viewpoints, give way to political passivity as the smoldering fear factor is fanned into open flame and everyone is expected to fall in line to support the war effort. This is, of course, not new to American social work. The early years of the $20^{\text {th }}$ century saw many social workers castigated and ostracized for their so-called communist leanings, which included such nefarious and socially destabilizing activities as calling for a forty-hour work week, the elimination of child labor, the provision of sanitation services for inner city immigrant groups, and the right of workers to organize (Ife, 2001).

For social work educators and field practitioners the new national security state offers new opportunities and creates new risks. Increasingly, educators are being challenged to more fully prepare their students for the realities of practice in a climate fraught with new fears and uncertainties. Section two of the Patriot Act virtually guarantees that government agents will have unprecedented access to a wide range of client records held by libraries, insurance companies, schools, and social service agencies. In this new environment, young social workers still unaccustomed to the rigors of working with marginalized clients and the applied ethics of protecting client rights will become prime targets of agents seeking information on questionable citizens and non-citizens alike.

There a several things social work educators can do. First, we must do a better job in educating our students to the new realities of practice. We must make sure that they have a rigorous knowledge of the laws and ethical guidelines insuring confidentiality. And, we must work together to strengthen them. We must help our students understand that self-determination means more than encouraging personal choice but includes standing firm against efforts to clamp down on freedom of speech and freedom of association. The absence of these protections serve to isolate refugee/immigrant groups and make them more vulnerable to the onslaughts of intrusive government. We can also encourage our field students, fellow faculty and agency personnel to be involved in broad coalitions devoted to preserving and restoring privacy and civil protections. These activities might include lending expertise and vocal support for protecting personal and confidential information, helping agencies to draft and implement stricter policies on confidentiality 
and privacy, and becoming allies and advocates with other social service providers to fight any effort where citizens are asked to spy and inform on other citizens.

\section{CONCLUSION}

A new form of rampant and unremitting insecurity has replaced civil freedoms and the constitutional protections of democracies. The United States has become the world's newly aggrieved giant. It claims its absolute right to act on behalf of itself and its citizens-alone, always and in every circumstance-to wage pre-emptive war justified only by its own internal logic and store of facts and to force democracy at the point of a gun on any nation in the ideological belief that only brutal dictators sponsor terrorism. Although the Patriot Act is currently undergoing review by the Senate Judiciary Committee, there is still great pressure to permanently legalize increased government snooping on citizens and to enact ever tighter controls on political dissent and organized advocacy. The land of the free and home of the brave is giving way to the sobering realization that we are a nation perpetually at war, chronically frightened by unseen enemies and paralyzed by phantasms of fear.

This paper has reviewed the sordid history of national security efforts to muzzle dissent and free speech in times of national crisis. It has provided a graphic picture of the high cost of allowing such efforts to go unchallenged. Social work is in the front lines of this new domestic war on terrorism. It is being asked, paradoxically, to be both servants of the dispossessed and spies upon the marginalized. If the fearmongering triumphs in creating an environment where the innocent lives of the most vulnerable in our nation's people are sacrificed in a delusional attempt to protect ourselves then we will have already lost the fight. Long before any government succeeds in controlling and institutionalizing deeply undemocratic practices, the seeds of tyranny would already have been planted in the years and perhaps decades proceeding. Our times are perilous not just because of the threat of terrorist attack but because of the slow and almost imperceptible erosion of civil liberties. This gradual decline, if left unchecked, will one day bear fruit in a society shunted away from freedom and burdened under the heavy yoke of centralized thought control and the criminalization of free speech. What role will social work play in this stealthily encroaching Orwellian world?

\section{References}

American Association of University Professors, Academic freedom and national security in a time of crisis. (n.d.). Retrieved March 9, 2005 from http:// www.org/statements/REPORTS/911report.htm

Aguirre, A., \& Turner, J. H. (2004). American ethnicity: The dynamics and consequences of discrimination ( $4^{\text {th }}$ ed.). Boston: McGraw-Hill.

Brinkley, A. (2003). A familiar story: Lessons from past assaults on freedoms. In R. Leone \& G. Anrig (Eds). The war on our freedoms: Civil liberties in an age of terrorism (pp. 23-46). New York: Public Affairs Press.

Brown, C. (Ed.). (2003). Lost liberties: Ashcroft and the assault on personal freedom. New York: The New Press.

Chang, N. (2002). Silencing political dissent. New York: Seven Stories Press. 
Cole, D. (2003). The course of least resistance: Repeating history in the war on terrorism. In C. Brown (Ed.). Lost liberties: Ashcroft and the assault on personal freedom (pp. 13-32). New York: The New Press.

Cole, D. (2004, October 4). Taking liberties: Ashcroft 0 for 5,000. The Nation, 279(10), 6, 20.

Cole, D., \& Dempsey, J., (2002). Terrorism and the Constitution: Sacrificing civil liberties in the name of national security. New York: The New Press.

Foner, E. (2001, October 8). The most patriot act. The Nation. Retrieved January 17, 2005, from http://www.thenation.com/docprint.mhtml?i=2001008\&s

Greider, W. (2004, June 21) Under the banner of the 'War' on terror. The Nation, 278(24), 11-18.

Hentoff, N. (2003). The war on the Bill of Rights and the gathering resistance. New York: Seven Stories Press.

Ife, J. (2001). Human rights and social work: Towards rights based practice. Cambridge: Cambridge University Press.

Leone, R., \& Anrig, G. (Eds.). (2003). The war on our freedoms: Civil liberties in an age of terrorism. New York: Public Affairs Press.

McDougall, G. (2004, October). Shame on our own house: How segregation and racism has fed U.S. resistance to international human rights treaties. The American Prospect, A21-A23.

Pearlstein, D. (2004, October). Rights in an insecure world: Why national security and civil liberty and complements. The American Prospect, A7-A10.

Piven, F. F. (2004). The war at home: The domestic costs of Bush's militarism. New York: The New Press.

Reichert, E. (2003). Social work and human rights: A foundation for policy and practice. New York: Columbia University Press.

Romero, A. D. (2003). Living in fear: How the U.S. government's war on terror impacts American lives. In C. Brown (Ed.). Lost liberties: Ashcroft and the assault on personal freedom (pp. 112-131). New York: The New Press.

Safire, W. (2002, November 2). You are a suspect. The New York Times, 35.

Senate Judiciary Committee. (2001, December 6). Department of Justice oversight: Preserving our freedoms while defending against terrorism-Testimony on Attorney General John Ashcroft. Retrieved April 24, 2005, from http://judiciary.senate.gov/testimony.cfm?id=121\&wit_id=42

Vanlandingham, J. (2005, March 23). Capitol bill aims to control 'leftist' profs. The Independent Florida Alligator. Retrieved March 25, 2005, from http:// www.alligator.org/pt2/050323freedom.php

\section{Author's note:}

Address correspondence to: Fred H. Besthorn, Ph.D., Associate Professor, Department of Social Work, Sabin 33, The University of Northern Iowa, Cedar Falls, Iowa 50614. Email: fred.besthorn@uni.edu. 